vol. 23, $n^{\circ} 2$ | 2019

Varia

\title{
Benoît Garnot, Une histoire du crime passionnel. Mythe et archives
}

Paris, Belin, 2014, 268 p., ISBN : 978-2701182872

Pieter Spierenburg

\section{(2) OpenEdition \\ Journals}

Electronic version

URL: https://journals.openedition.org/chs/2596

DOI: $10.4000 /$ chs. 2596

ISSN: 1663-4837

\section{Publisher}

Librairie Droz

Printed version

Date of publication: 18 December 2019

Number of pages: 131-132

ISSN: 1422-0857

\section{Electronic reference}

Pieter Spierenburg, "Benoît Garnot, Une histoire du crime passionnel. Mythe et archives", Crime, Histoire \& Sociétés / Crime, History \& Societies [Online], vol. 23, n² | 2019, Online since 06 May 2020, connection on 19 April 2022. URL: http://journals.openedition.org/chs/2596 ; DOI: https://doi.org/10.4000/chs. 2596

This text was automatically generated on 19 April 2022.

(c) Droz 


\section{Benoît Garnot, Une histoire du crime passionnel. Mythe et archives}

Paris, Belin, 2014, 268 p., ISBN : 978-2701182872

Pieter Spierenburg

\section{REFERENCES}

Benoît Garnot, Une histoire du crime passionnel. Mythe et archives, Paris, Belin, 2014, 268 p., ISBN : 978-2701182872

1 Benoit Garnot is surely a prolific writer. I have made no attempt to count his books but the number is considerable, certainly if you include the edited ones. And here we have a history of the crime passionnel or crime of passion. The Frenchness of the concept is usually acknowledged in English by refraining from a translation.

When I submitted the manuscript of Written in Blood, I had once or twice referred to the two crimes related in it as crimes passionnels. The publisher's external reviewer adamantly censured me for this: you cannot refer to any murder as a crime passionnel before the nineteenth century. Not laying particular value on the concept, I duly omitted it from my text. A few years later, when preparing my History of Murder, I followed the analysis of such authors as Joëlle Guillais, Ruth Harris and Ann-Louise Shapiro who share a specific understanding of crime passionnel: a popular rather than legal concept, in fact no more than a label that contemporaries often attached to an offense that involved "killing for love" (including non-lethal vitriol attacks). The use of this label was more or less confined to a specific period, c. 1870-c. 1930. Although particularly influential in France, other European nations also ascribed certain offenses to crime passionnel or a similar concept. All this resulted from the confluence of at least three trends: the growing involvement of forensic experts in criminal trials, the sympathies of juries and behind them a large part of the public and, thirdly, the tendency of criminologists to set passionate offenders apart from born criminals and the like. The end date of 1930 marked a decline of sympathy among expert groups as 
well as the lay public. In short, crime passionnel was a construct, not a "real" category within the spectrum of offenses.

Benoit Garnot, who refers to only one author of the trio just mentioned, has quite the opposite thesis. He posits that crime passionnel represents a definite category of crime and that it occurs in all historical periods. In his introduction he defines it as a murder or attempted murder that is driven in one way or another by the passion of love. Subsequently, the first chapter distinguishes several types and sub-types of passionate crimes, including the traditional killing of an unfaithful wife and/or her lover for reasons of honor. Even male serial killers who victimize women that resemble a partner who once deserted them are included. In addition, Garnot deals with passionate offenses not only in real life but also in fictional stories, in particular Greek mythology. We hear about Medea several times. The subtitle "myths and archives" is meant to reflect this dual orientation. This makes the ancient Greek tales about gods and (tragic) heroes the principal non-French cases that the author discusses. For the rest, the book concentrates on France with occasional digressions to other countries, but not to the Netherlands.

4 The chapters are ordered thematically. After the categorization of chapter one, the author tries to identify common characteristics of passionate offenders. The result is largely negative; they are from all social milieus, for example. The only common trait is psychological: they share either an excessive narcissism or a sickly jealousy or both. The next chapter analyzes the process from disappointment in love, experienced by many others that do not become killers, to the fatal act. This chapter includes a brief discussion of Norbert Elias' theory of civilizing processes. Garnot does not reject it in its totality, but he believes that Elias' theory necessarily implies that all offenses prior to the last three centuries or so are impulsive acts. By contrast, he argues, most crimes passionnels were premeditated. Incidentally, this is true for most revenge murders as well. Subsequent chapters are devoted to public attitudes, with writers, journalists and criminologists as a proxy, and the legal treatment of passionate offenders. This neat thematic ordering is repeatedly offset by chronological disorder. Garnot jumps back and forth across time, presenting cases from the middle ages followed by examples from the twenty-first century and then going back in time once more.

The fact that the author considers crime passionnel as a phenomenon of all ages does not mean that he completely rejects the chronology claimed by the scholars who view it as a label. This chronology turns up in his analysis but with a different emphasis. What others consider as the period when the construct of crime passionnel exerted its spell, is a particular phase in the long history of the offense for Garnot. According to him, crimes of passion became more visible in the course of the nineteenth century and more likely to result in relatively light punishments or even acquittals. Although pardons were issued in the sixteenth century as well, in particular for honor-related crimes of passion, severe punishment was the rule in the early modern period. Garnot further agrees that from about 1870 criminologists set the passionate offender apart from the born criminal and he observes a change of attitudes among experts and the general public alike beginning in the interwar period and setting through after the mid-twentieth century. In the twenty-first he still sees a lot of criminels passionnels, but especially the public wishes them to receive severe punishment again, identifying not with them but with their victims. 
6 All this leads to the following overall thesis: Passionate offenders have been around throughout history, sharing the psychological traits of an excessive narcissism and jealousy. In its turn these traits result from a lack of affection suffered during childhood. Once more, this lack of affection affects children of all historical eras, but the rise of the intimate nuclear family from the eighteenth century on has increased the number of those suffering from it. As a consequence, the number of crimes passionnels is on the rise as well, becoming fully visible in the nineteenth century. Finally, today's frequency of broken and reconstituted families means that the preconditions for experiencing a lack of affection are present to an even greater extent now. Therefore, Garnot predicts that crime passionnel will remain with us, becoming perhaps even more common than ever.

\section{AUTHORS}

\section{PIETER SPIERENBURG}

Erasmus University Rotterdam 